\title{
Medication-Assisted Treatment Should Be Part of Every Family Physician's Practice: Yes
}

\author{
David Loxterkamp, MD \\ Seaport Community Health Center, Belfast, Maine \\ Ann Fam Med 2017;15:309-310. https://doi.org/10.1370/afm.2103.
}

Caminante, no bay camino, se bace camino al andar.

Traveler, there is no path; the path is made by walking. Antonio Machado

$\mathrm{L}$ et me tell you the story once more. Amanda was 19 , pretty and smart, a college student at a nearby university who had returned home for the weekend. Her father, a long-standing patient of mine, had called from the emergency department to say that she was there with a bad stomach virus. But it was Amanda who whispered to me that she was withdrawing from heroin. I managed her detoxification with IV fluids, anti-emetics, and alpha-blockers, but had nothing to offer her beyond that. So she cycled through the emergency department twice more before her father drove her to an out-of-state residential treatment program. That was in 2003, before I knew about Suboxone and received training to prescribe it. Since then, our office has treated hundreds of patients with medication-assisted treatment, many of whom turned their lives around and allowed us to play a role in their transformation.

That was my conversion experience. Getting involved often requires a personal hook: one patient ${ }_{i}$ a confrontation with the brutality of the disease; the certainty you were chosen to make a difference.

Twelve years later, I am still involved. Why? For Amanda, who reminds me of my daughter. How could I insist that someone come to my daughter's aid, should she need it, if I refused to help Amanda now? For my sister, who dabbled in drugs but died instead of emphysema hastened by the grip of nicotine depen-

Conflicts of interest: author reports none.

\section{CORRESPONDING AUTHOR}

David Loxtercamp, MD

Seaport Family Practice, PA

453 Schoodic Drive

Belfast, ME 04915

dr.loxterkamp@verizon.net dence. For Joey, who is struggling to cope with a sober life after witnessing his mother's stabbing death at the hands of his drug-addled brother. For Dale, who lost 2 relationships, the custody of his children, countless jobs, thousands of dollars, and 2 years of his life in prison. For Tony, who medicated his emotions with marijuana and oxycodone but can now, after 4 years in our program, finally speak of his deceased family members without sobbing. For the stories I hear when I ask, "How did a good person like you end up in a program like ours?" The tales are personal, upsetting, raw, compelling. And now all too familiar. The wonder is that patients reveal themselves at all, given their burden of shame and regret. Patients with addiction are marked by a disease that criminalizes them and compels a certain degree of secretiveness and suspicion for the sake of survival. Learning to trust again takes time.

I am still involved because I am a doctor and this is the epidemic of our time, a social tsunami that can be traced to my prescription-and yours. We lost 4 young people in our rural county this past month, in a state that has seen deaths from opioid overdose rise steadily over the past decade-and 25\% higher this year over last. ${ }^{1}$

I am involved because it restores my faith in family medicine, where relationships still matter. Where social structures are the determinants of success: familial support, sober friendships, safe housing, reliable transportation, affordable medical and mental health care. Where we know the stakes are high, not just for our patients, but for their children, who are the collateral damage of each generation. Where a commitment to change is the essential ingredient for recovery, made manifest in small, uneven, but steady signs of progress.

Addiction is a chronic disease that is decimating our communities. We need no other reason to embrace its treatment within every primary care practice. Yes, it will require a special workflow, but so does the management of diabetes or depression. Yes, your patients will need many hands to help them, but you are already committed team-based care. Yes, you 
lack street knowledge on issues such as child custody, employment options for felons, and the rules around subsidized housing; that is why you surround yourself with peer experts in group therapy. And yes, starting a recovery program will require leadership to overcome the inertia of your staff and colleagues, because you innately know that everyone must be on board to do the work well.

No one is better qualified to treat addiction than a family doctor. We know that substance use disorder_-of all diseases_-cannot be cured by drugs alone. We believe that hearing the story and nurturing a relationship are indispensable modalities of treatment. We are willing to become what our patients require: their weekly dose of parental affection, the arbiters of fairness and accountability, a buttress against their flagging selfesteem, the partner who hears more than their anger, or a compass for those without purpose or direction.

Let us be the standard-bearers for a communitybased response to the opioid epidemic. While there is a critical need for informed public health policy, our work is on the ground. There are no signposts here, only patients alongside us. No one expects us to fix the problem, least of all the patients we treat. Our challenge is to "be there" for them, acknowledge their struggle, and maintain what is still, too often, a narrow, uncertain, and unmarked path toward recovery.

To read or post commentaries in response to this article, see it online at http://www.AnnFamMed.org/content/15/4/309.

Key words: buprenorphine, naloxone drug combination; opioid, opiate substitution therapy; opioid-related disorders; prescribing patterns, physician, primary health care

Submitted September 7, 2016; submitted, revised, March 21, 2017; accepted March 31, 2017.

\section{References}

1. Lawlor J. Drug overdose deaths in Maine now averaging one a day. Portland Press Herald. November 14, 2016.

\title{
POINT/COUNTERPOINT
}

\section{Medication-Assisted Treatment Should Be Part of Every Family Physician's Practice: No}

\author{
Richard R. Hill, $M D, P b D^{1,2,3}$ \\ 'Neighborhood Family Practice, Cleveland, Ohio \\ ${ }^{2}$ Case Western Reserve University School of Medicine, Department of Psychiatry, Cleveland, Ohio \\ ${ }^{3}$ Cleveland Clinic Foundation, Department of Psychiatry, Cleveland, Ohio
}

Ann Fam Med 2017;15:310-312. https://doi.org/10.1370/afm.2102.

$\mathrm{T}$ The magnitude and tragedy of the national opioid epidemic has prompted The Office of National Drug Control Policy and the US Department of Health and Human Services to prioritize increasing access to medication-assisted treatment. ${ }^{1,2}$ The Drug Addiction Treatment Act of $2000^{3}$ enables physicians who complete an 8-hour online course to prescribe schedule III, IV, and V opiates, including buprenorphine/buprenorphine naloxone $(\mathrm{B} / \mathrm{BN})$ for opioid use

Conflicts of interest: author reports none.

\section{CORRESPONDING AUTHOR}

Richard R Hill, MD, PhD'

Neighborhood Family Practice Medical Center

3569 Ridge Rd

Cleveland, $\mathrm{OH} 44102$

rhill@nfpmedcenter.org disorders in settings other than outpatient treatment centers such as methadone maintenance clinics. Despite the potential for great expansion, use of $\mathrm{B} / \mathrm{BN}$ remains limited. ${ }^{4-6}$ The need to expand the reach of medicationassisted treatment across the country has led many policy makers, academics, and some physicians to suggest that primary care physicians be at the front lines of this effort. While the number and geographic distribution of primary care physicians makes them likely candidates to deliver the care, there are a number of other factors that make this a poor decision for both primary care physicians and patients.

\section{SPECIALIZED TREATMENT REQUIRED}

Patients requiring $\mathrm{B} / \mathrm{BN}$ have likely exhausted or failed at all other forms of nonmaintenance treatment inter- 